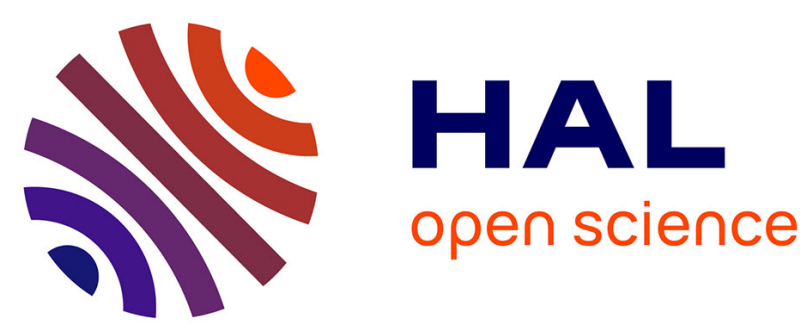

\title{
Challenging Platonic Erôs
}

Olivier Renaut

\section{To cite this version:}

Olivier Renaut. Challenging Platonic Erôs: The Role of Thumos and Philotimia in Love. Ed Sanders; Chiara Thumiger; Christopher Carrey; Nick Lowe. Erôs in Ancient Greece, Oxford University Press, pp.95-110, 2013, 9780199605507. 10.1093/acprof:oso/9780199605507.003.0007 . hal-01322948

\section{HAL Id: hal-01322948 \\ https://hal.science/hal-01322948}

Submitted on 29 May 2016

HAL is a multi-disciplinary open access archive for the deposit and dissemination of scientific research documents, whether they are published or not. The documents may come from teaching and research institutions in France or abroad, or from public or private research centers.
L'archive ouverte pluridisciplinaire HAL, est destinée au dépôt et à la diffusion de documents scientifiques de niveau recherche, publiés ou non, émanant des établissements d'enseignement et de recherche français ou étrangers, des laboratoires publics ou privés. 
O. Renaut, "Challenging Platonic Erôs. The Role of Thumos and Philotomia in Love", in E. Sanders, C. Thumiger, C. Carey \& al. (ed.) Erôs in Ancient Greece, Oxford, Oxford University Press, 2013, p. 95-110.

\section{CHALLENGING PLATONIC ERÔS THE ROLE OF THUMOS AND PHILOTIMIA IN LOVE.}

Plato's Dialogues continue to challenge our common definition of love. Whereas we commonly understand the primary meaning of love as an intense feeling addressed to an individual and attachment to his uniqueness - what we may call "personal love" hereafter -, Plato famously defines erôs as a force that drives each individual towards an object that appears to be rather abstract: Beauty (kalon). Platonic love provides the individual with happiness and leads him to virtue by knowledge of the Good. This intellectualized form of love goes together with a condemnation of sexual attachment and greediness, starting with the Symposium and the Phaedrus through to the Laws. It is therefore commonly argued that, for Plato, "personal love" cannot be an end in itself. As Vlastos has shown, love for an individual is a mere symptom of human deficiency, for the only thing truly worth loving is the Good, in a rather egoistic way. ${ }^{1}$ It is then a small step from the condemnation of inferior love whose paradigm is sexual attachment to an overall rejection of "personal love", insofar as the lovers have not fulfilled the process of ascending the so-called "ladder of love" depicted in the Symposium (210a-212a). ${ }^{2}$

Real Platonic love, the only one of value, is the philosophical love for the Good. ${ }^{3}$ What remains unclear, though, is whether real philosophical love represents a distinct kind of love, which has nothing to do with inferior kinds. ${ }^{4}$ If this were the case, how would a nonphilosopher understand that philosophical love is true erôs? And, if it is even possible, how could inferior kinds of love be used as means of experiencing love of Forms, and, even more so, the Form of the Beautiful (kalon)? $?^{5}$ A way of rehabilitating "personal love" in Plato, and of organizing different kinds of love into a non-exclusive hierarchy, is to follow Socrates when he decides on a typology of erôs at the end of the Republic. As Socrates shows in Book IX of the Republic, there are three main types of desires in the human soul: bodily desires (thirst, hunger, sexual desires, and money as a means of buying whatever one desires), desire

I'm grateful to the audience of the conference "Erôs in Ancient Greece", and especially Ed Sanders and Chiara Thumiger and Lee Brooks for their helpful remarks and objections. I also thank the "Institut de Recherches Philosophiques" (EA373) of Université Paris Ouest - Nanterre-La Défense for its support, Christopher Robertson and Lee Brooks for having corrected my English.

${ }^{1}$ Vlastos (1981).

${ }^{2}$ This opposition between an exclusive platonic love and a more common one has to be qualified. For an example of how love can be more inclusive, allowing sexual intercourse for instance, see Gill (this volume) on the stoic interpretation of platonic love.

${ }^{3}$ Vlastos's ground-breaking article has been much discussed. See first Nussbaum (2001), who opposes the Symposium to the Phaedrus (ch. 6 and 7) on the grounds that, in the latter, Plato acknowledges the importance of sensibility, passions and personality in the experience of love (p. 213-23). Price (1981) maintains, more accurately, that the conception of love in the Symposium is an "inclusive" one (the philosophical love contains the others), whereas the Phaedrus ends by discarding inferior forms of love, symbolized by the desires of the two horses. See also the critical notes by Rowe (1990). White (1990) shows in what sense "personal love" could fit the Platonic picture of philosophical love. Finally, see Gill (1990), who shows that the myth aims at educating the lovers to respect and esteem each other (p. 76-78) but that it is not an end in itself; the main goal is to unify one's soul in experiencing philosophical love, i.e. by submitting the desires to the rule of reason ( $p$. $82 \mathrm{ff}$.$) .$

${ }^{4}$ For a detailed account of Plato's strategy in transforming the common conception of love in the Phaedrus, see Cairns (this volume).

${ }^{5}$ See the recent attempt of Carone (2006) to combine universal and particular objects of love in the experience of the philosopher in the Symposium. 
for honour and victory, and desire for knowledge. These three types of desire define three corresponding types of man: the profit-loving man (philochrêmatos), the victory and honourloving man (philonikos kai philotimos) and the philosopher (philosophos) (Resp. IX, 580d$581 \mathrm{~b}$ ). The opposition between the first and the last character reaches its climax when Socrates depicts the similarities and differences between the violent erôs growing in the tyrant's soul, and the erôs of the philosopher. ${ }^{6}$ Less attention has been paid to the other kind of love, philotimia, which arises not from the desiring part of the soul but from its intermediary part: thumos. The philotimos seems at first sight to be an unfamiliar image of a lover, but he is actually the only one who feels what we can recognize as a "personal" attachment to somebody, as well as care for the reputation and the image of his lover and of himself. Indeed, and contrary to the appetitive type of love, thumoeidic love as described in the Phaedrus is not easily discarded, insofar as a smoother treatment seems to be reserved to the thumoeidic lovers (Phdr. 256b-e). ${ }^{7}$ This chapter aims to show that philotimia is seen by Plato both as a dangerous challenge to philosophical love and also as an opportunity to use the energy expended by the psychic function from which this love comes, thumos, in order to serve philosophical goals. I shall begin with an analysis of the role of philotimia in the speeches of Phaedrus and Diotima in the Symposium. Then, I shall explain, on the grounds of the tripartite soul in the Republic, how philotimia can be used as a lever for philosophical erôs in the Phaedrus, before concluding on its political use.

\title{
Philotimia as a wrong basis for love
}

In the first praise speech of the Symposium, Phaedrus makes philotimia the sense of honour and shame, the most important lever of erôs, and the instrument of our own flourishing and self-construction through others. ${ }^{8}$

\begin{abstract}
I cannot say what greater good there is for a young boy than a gentle lover, or for a lover than a boy to love. There is a certain guidance each person needs for his whole life, if he is to live well; and nothing imparts this guidance - not high kinship, not public honor, not wealth - nothing imparts this guidance as well as Love (ov̌ $\tau \varepsilon$

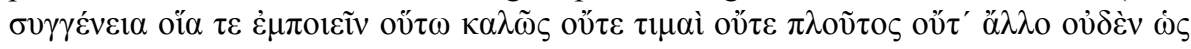
है $\omega \varsigma)$. What guidance do I mean? I mean a sense of shame at acting shamefully, and a sense of pride in acting well (

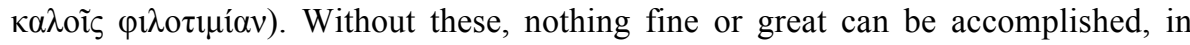
public or in private. What I say is this: if a man in love is found doing something shameful, or accepting shameful treatment because he is a coward and makes no defense, then nothing would give him more pain than being seen by the boy he loves - not even being seen by his father or his comrades. We see the same thing also in the boy he loves, that he is especially ashamed before his lover when he is caught in something shameful (Symp. 178c3-e3, trans. Nehamas and Woodruf) ${ }^{9}$
\end{abstract}

${ }^{6}$ On erôs and the tyrant, see Larrivée (2005).

${ }^{7}$ See Nussbaum (2001), ch. 3.

${ }^{8}$ This speech has long been neglected by commentators as a quite conventional speech. However, it makes much more sense to take this passage as a first step towards a transformation of Homeric ethics to fit the Platonic conception of love: see Wersinger (2001) 243-248, and Corrigan and Glazov-Corrigan (2005) 51-56, for an accurate analysis of this speech.

${ }^{9}$ There is some difficulty in translating erôs by love in this passage, for we certainly expect the word philia instead, conveying the idea of a deep attachment rather than a pederastic relationship including sexual attachment. But Phaedrus uses erôs here purposely, as it becomes clear with the examples he chooses at the end of his praise speech: Alcestis, Orpheus and Achilles. 
O. Renaut, "Challenging Platonic Erôs. The Role of Thumos and Philotomia in Love", in E. Sanders, C. Thumiger, C. Carey \& al. (ed.) Erôs in Ancient Greece, Oxford, Oxford University Press, 2013, p. 95-110.

For Phaedrus, erôs is the foundation of ethics. Through shame and philotimia, one becomes better, and better able to care for oneself. Phaedrus compares erôs to three other types of social relationships: philia (especially between members of the same family or genos), honour-based relationships (which may refer to a more extended sphere of social and political relationships), and wealth-based relationships. Faced with these three relationships, erôs remains the only one that leads the individual to real happiness (eudaimonia). According to Phaedrus, the sense of honour enables the lover to take up the challenge of showing grace, generosity and magnanimity in front of his lover.

It is tempting to say that Phaedrus's speech is a mere echo of popular morality and expresses concern for what people say. The value of the individual's behaviour and actions would then depend on the way witnesses evaluate it, according to existing social norms. There would only be a difference in degree between the shame experienced in front of the beloved and in front of any other individual. But this interpretation is misleading. The rule of construction of selfhood is assuredly heteronomous, insofar as selfhood depends on how a particular witness, the lover, considers it. But this does not mean that the values advocated by the parents, the philoi, and others in general, have the same function as the ones implied in a relation of love. Because the lover cares for his beloved far more than he does for his parents, friends and others, the beloved functions as a real motivation for the lover to show an ideal image of himself. For Phaedrus, absolute timê is achieved when one is ready to sacrifice his life, being entirely at the lover's behest. ${ }^{10}$ In experiencing shame and philotimia in front of the beloved, one commits oneself to values, which one could have otherwise only superficially approved. In other words, philotimia and shame are, according to Phaedrus, means for the individual to experience the values he is committed to as true ones, and to seek new challenges for himself.

However, it seems at first sight that Phaedrus is not really consistent in opposing a sense of honour and shame, which comes from erôs, and the attachment to social and political marks of honour (timai). There seems to be a contradiction in the fact that Phaedrus first points out the inanity of founding happiness on timai, and then makes philotimia the cause of becoming better. But we should assume here that Phaedrus gives the concept of timê different meanings. ${ }^{11}$ In the first case, timê seems to refer to a kind of possession (civic honours, prerogatives, or even presents), whereas the latter, the one philotimia strives for, does not mean the product of the relation, but the value of the relation itself, so that selfhood is constructed through a sense of honour and shame, placing the other on a level beyond the possessions one can get from him.

Phaedrus's speech plays with a Homeric legacy. The persistent Homeric patterns, notably the mention of the hero's spirited force (menos) (178e3-179b3), and the use of the figure of Achilles as the paragon of courage (179e1-180b5), grace and sensibility at the end of the speech, are important clues of a link between erôs and philotimia, and even with their psychological seat, thumos. If we go back to Homeric epics, erôs is likely to be found in the

${ }^{10}$ Self-sacrifice could first be thought to be an expression of perfect philia, as Aristotle states in Eth. Nic., IX.8, 1169a18 ff., where he employs the same verb (i $\pi \varepsilon \rho \alpha \pi \circ \theta v \eta \eta ́ \sigma \kappa \omega)$ to show how philoi are ready to die for each other (I am grateful to Ed Sanders for drawing this passage to my attention), as Phaedrus to describe the sacrifice of Alcestis and Achilles (Symp. 179b4, 180a1). Whether or not Aristotle has the Symposium in mind, it underlines the oddity of Phaedrus's speaking of erôs when we expect philia. However, it might also mean that for Phaedrus, erôs is even more inclusive than philia, for a perfect lover such as Achilles not only "dies for"

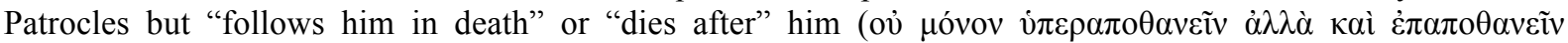
$\tau \varepsilon \tau \varepsilon \lambda \varepsilon v \tau \eta \kappa o ́ \tau 1,180 \mathrm{a} 1)$.

${ }^{11}$ On the meaning of time, especially in Homeric Epics, see Riedinger (1976) who resists the idea that timê is reducible to a mere ransom. For an opposite and resisting view, see Adkins (1982), who seems to acknowledge the traditional platonic criticism of philotimia. 
O. Renaut, "Challenging Platonic Erôs. The Role of Thumos and Philotomia in Love", in E. Sanders, C. Thumiger, C. Carey \& al. (ed.) Erôs in Ancient Greece, Oxford, Oxford University Press, 2013, p. 95-110.

character's thumos, together with philia and passions of the like. ${ }^{12}$ Furthermore, it is in their thumos that heroes feel anger, hatred or delight when watching their enemy perish. ${ }^{13}$ Phaedrus is thus recalling a traditional link between erôs and thumos, the latter being the aggressive side of the former. ${ }^{14}$

Furthermore, it is interesting to note that Phaedrus' speech mentions all the characteristics of the thumos that will be found in the Republic: an acute sensitiveness to what is good and just through a sense of honour and shame; marks of manliness; a spontaneous manner of showing one's commitment to the values one believes in; a propensity to philotimia and, more generally, to a competitive spirit, leading one to seek out new challenges. It is likely that in the Republic, Plato does not discard this Homeric legacy concerning the sensitivity to timê, which is rooted in the thumos of the auxiliaries.

Before we turn to the main criticism Diotima will make in her discourse against this thumoeidic ideology, we should compare this speech to its "echo" in Plato's dialogues, namely Lysias's speech in the Phaedrus. When reading Phaedrus's speech in the Symposium, we could have expected the word philia to occur instead of that of erôs, as if Plato were purposely transposing a Homeric model of personal relationships to fit artificially with erôs. As a counterpoint to Phaedrus's speech, Lysias's discourse in the Phaedrus, read by the same Phaedrus he is in love with, employs the same notions of shame and sense of honour as virtues. ${ }^{15}$ But Phaedrus's speech is reversed, for Lysias praises the non-lover, and criticizes the incontinence and hybris of the lover. Thus, Lysias dissociates philotimia from aischune, the first being related to envy and jealousy.

\begin{abstract}
Now suppose you're afraid of conventional standards ( $\tau$ òv vó $\mu$ ov $\tau$ òv $\kappa \alpha \theta \varepsilon \sigma \tau \eta \kappa o ́ \tau \alpha$ $\delta \varepsilon ́ \delta о к \alpha \varsigma)$ and the stigma that will come to you if people find out about this. Well, it stands to reason that a lover - thinking that everyone else will admire him for his

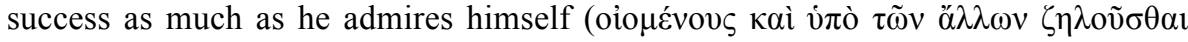

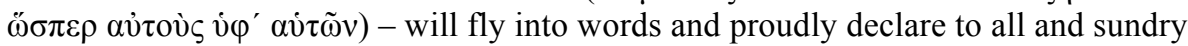

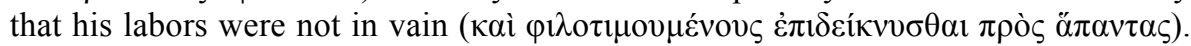
Someone who does not love you, on the other hand, can control himself and will choose to do what is best, rather than seek the glory that comes from popular

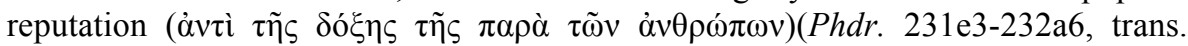
Nehamas and Woodruf).
\end{abstract}

Unlike the lover, who is moved by philotimia, the non-lover is able to show reserve:

\footnotetext{
${ }^{12}$ Numerous formulae indicate that thumos is that by which we feel a certain attachment to something. Such feelings range from kindness and philia between comrades, friends, or members of the family (Il. I, 196, 209; V, 243, 826; IX, 486; X, 531; XI, 520, 608; XIX, 287; XXIV, 236, 748, 762; Od. VI, 20; XIV, 146) to mere sexual attraction as in the episode of the seduction of Zeus (Il. XIV, 315) or enchantment as in the appearance of Penelope in front of her suitors (Od. XVIII, 212, 282), through to what we can call "love" between husband and wife for example, including both philia and a sexual relationship (Il. IX, 340-343, 398; Od. XVII, 553-555).

${ }^{13}$ See for instance Il. I, 196; I, 209; I, 562; V, 243; V, 826; IX, 341; IX, 398; IX, 486; XIV, 315; XIX, 287; XXIII, 548; XXIII, 595; XXIV, 762; Od. VI, 23; XIV, 146; XV, 20; XVIII, 212.

${ }^{14}$ Hesiod, Theog. 223-225, where we are told that Philotês is born at the same time as Nemesis, and Eris which affect the thumos (karterothumos). See also Sappho, fr.1 (West), where the poetess prays to the Divinity to strengthen her thumos, becoming the active, or even aggressive side of her deceitful erôs, whether her thumos is defeated by nauseous disease (1. 4), or succeeds in conquering her love (1. 18 and 1. 27).

15 Everything opposes the two discourses. However, Wersinger (2001) 248-257, has shown perfectly well that Phaedrus and Lysias defend an ideal of a relationship based on well-considered charis which implies the self-effacing of the individual. But this reserve (aidôs) does not preclude competitive behaviour for Adkins (1996)
} 
O. Renaut, "Challenging Platonic Erôs. The Role of Thumos and Philotomia in Love", in E. Sanders, C. Thumiger, C. Carey \& al. (ed.) Erôs in Ancient Greece, Oxford, Oxford University Press, 2013, p. 95-110.

[No, it's proper, I suppose, to grant your favours] not to people who achieve their

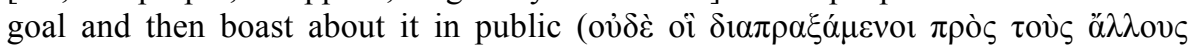

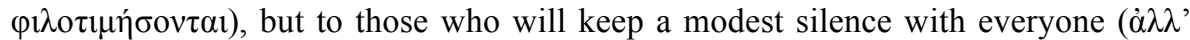

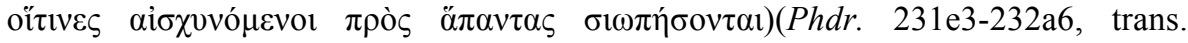
Nehamas and Woodruf).

In opposing Phaedrus and Lysias's discourses, Plato aims to criticize philotimia as a good motivation in erotic relationships. Later in the Phaedrus, giving his own version of Lysias's speech, Socrates playfully recognizes in the supposed non-lover a lover necessarily prone to

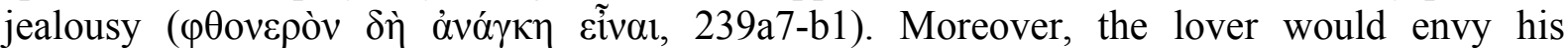

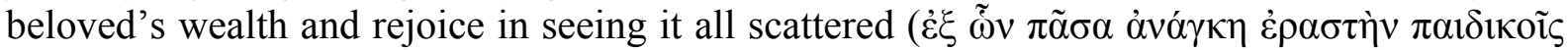

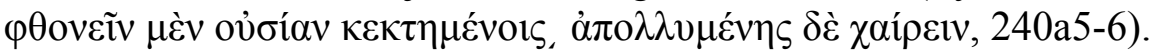

As a result of these multiple reversals, it can be argued that for Plato, and contrary to what Phaedrus and Lysias say, an erotic relationship which relies on either one or both philotimia and aidôs, is doomed to failure because of its attachment to an image of oneself, which is dependent on what others say. Phthonos will necessarily appear, transforming the erotic relationship into a theatrical scene, where the self is but an image of what his beloved wants him to be and, reciprocally, the beloved a potential opponent in the competition that leads to happiness. ${ }^{16}$

In response to Phaedrus' speech, Diotima's task consists in assuming the natural origin of philotimia in love without letting it fix the object of love on timê.

\begin{abstract}
"Be sure of it, Socrates. Look, if you will, at how human beings seek honour ( $\tau \grave{\eta} v$

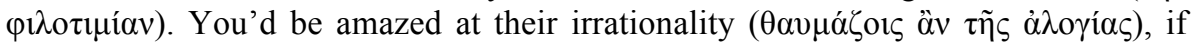
you didn't have in mind what I spoke about and if you hadn't pondered the awful state of love they're in, wanting to become famous and "to lay up glory immortal

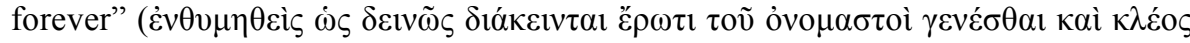

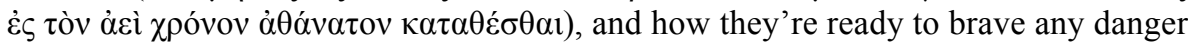
for the sake of this, much more than they are for their children; and they are prepared to spend money, suffer through all sorts of ordeals, and even die for the sake of glory. Do you really think that Alcestis would have died for Admetus," she asked, "or that Achilles would have died after Patroclus, or that your Codrus would have died so as to preserve the throne for his sons if they hadn't expected the memory of their virtue - which we still hold in honor - to be immortal $(\mu \grave{\eta}$

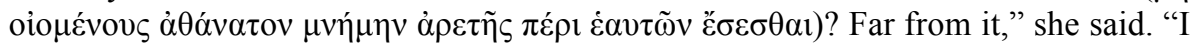
believe that anyone will do anything for the sake of immortal virtue and the glorious

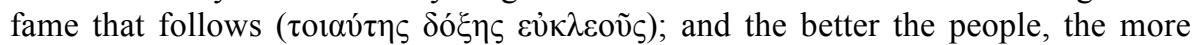

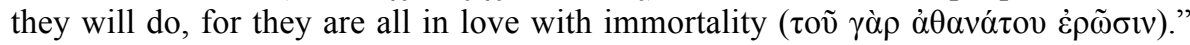
(Symp. 208c1-e1, trans. Nehamas and Woodruf)
\end{abstract}

Phaedrus's edifying conception of love according to which the lover seems to be entirely at the disposal of his beloved is refuted by a psychological analysis of the lover's real motives. Philotimia is a contradictory desire: through self-sacrifice, the lover clearly seeks a greater good: to die for somebody is nothing else than to die as a hero, i.e. overcome death by gaining immortality in renown. Diotima uses Phaedrus's own vocabulary and examples in order to deny that the object of love could be anything other than glory and fame. Using the example of Codrus, whose motivations are not erotic but political, Diotima denies that the role of the beloved is more important than the struggle for timê.

${ }^{16}$ See Phlb. 47e1-48a4, where erôs and thumos are ultimately related to phthonos. See Sanders (this volume), for a jealous woman driven by thumos. 
A twofold conclusion can be inferred from Diotima's speech: Phaedrus is right in saying that erôs is the foundation of ethics and of a set of values that leads to the Good, but he is wrong in making philotimia its achievement. Philotimia is an irrational desire ( $\alpha \lambda o \gamma o \varsigma$ ), for it leads the individual to prefer death as a way to acquire renown through immortality. Philotimia is then dangerous for two reasons: first, it transforms love into an edifying affair, exalting dramatic emotions; second, it fails to understand what is really, in love, the object to be valued. The philotimos focuses selfishly on the capacity of others to make him good, beautiful and virtuous. In other words, Plato denounces the propensity of the philotimos to love being praised at any cost, regardless of the real and objective value of actions and behaviour. Thus, for Plato, the philotimos remains dependent on what people think and say (through memory and renown) and fails to recognize what the real object of erôs is.

However, Diotima does not entirely dismiss philotimia as a whole. As irrational as philotimia may be, it remains an expression of a longing for a real object of love, immortality. Contrary to Lysias in the Phaedrus when he criticizes cupidity and lust, or contrary to Socrates in Book VIII of the Republic, Diotima rightly points out the efficiency of philotimia as a lever for virtuous behaviour. Indeed, the three examples of Alcestis, Achilles and Codros are illustrious ones; what is therefore questioned is not the effect of philotimia but the way those heroes have misconstrued the image of the object of love. What is at stake, then, is how the psychological force of philotimia could be a lever to attain real immortality.

\section{Educating thumos's force}

If the Symposium presents the inferior type of love experienced by the philotimos as ambiguous, it does not explain how it can be used as a means towards attaining true philosophic love. The tripartite model of the soul might throw light on how philotimia can be diverted to this end. ${ }^{17}$ In the Symposium, erôs is the name Plato gives to the fundamental desire which leads every single animal in the sensible world to seek its own good during its life, but the tripartite model can also be used in order to show both how different types of love could be classified on a scale of values, whose criterion would be their proximity to philosophy, and how philosophical love could proceed from a relatively inferior type of love. The link between the two intermediaries is philotimia. ${ }^{18}$ In Book IV of the Republic, Socrates presents what is called the tripartite psyche. The psyche is divided into three "parts" or rather three "functions", each of which is responsible for a kind of action or passion: the rational part (logistikon), the desiring part (epithumêtikon), and the intermediary part (thumoeides). ${ }^{19}$ The function of thumos is to value things, not evaluate them cognitively (which is the task of the logistikon, the rational part of the soul), nor desire them (which is the concern of the

${ }^{17}$ It would be misleading to oppose, as an objection, a so-called "static" hierarchical model of the soul, i.e. the tripartite model with thumos as an intermediary, to the more dynamic and unified one which has been depicted in the Symposium. Whereas Brès (1973), $308 \mathrm{ff}$., tries to show that the tripartite model, a static and hierarchical model of the soul, is an impoverishment of a more dynamic psychology which is found in the Symposium, Robin (1964) has consistently shown that this opposition is not relevant, especially in the Phaedrus.

18 This potential link between the tripartite soul, especially thumos, and philotimia, is clearly presented by Cairns (1993) 381-9. It might then be tempting to outline analogies between thumos and erôs regarding their function as "intermediaries", as Souilhé (1919) has tried to show, but, despite the resemblance regarding their function, thumos is not necessarily the seat of erôs.

19 Erôs as sexual appetite has been naturally associated with epithumêtikon in the post-platonic tradition. On this strong association and the physiological interpretation of what is understood as a passion in Galen, see Rosen (this volume). 
epithumêtikon). ${ }^{20}$ Angela Hobbs has brilliantly summed up its function, saying that "the essence of the human thumos is the need to believe that one counts for something, and that central to this need will be a tendency to form an ideal image of oneself in accordance with one's conception of the fine and noble". ${ }^{21}$ Valuing things means for each individual to be committed to his own values (laws, habits, norms), which will arouse two opposite emotions in him: anger (orgê, or sometimes thumos) when these values are threatened or despised (440c7-d6), and shame (aidôs or aischunê) when he himself fails to enact them (439e6-440a3, 440c1-c6). Central to the definition of the function of thumos is the idea of honour (timê). As we've seen in Phaedrus's speech in the Symposium, the greek word "timê" can refer to particular objects such as civic honour, special prerogatives given by public esteem, presents, etc. These objects are the expression of a complex network of social and political relationships, often referred to as the ideology of honour. ${ }^{22}$ In this network, one is able to form oneself through others, what they think and what they say (see esp. 364a6-b2, 413e5-414a4). But timê also means simply the "value" the individual gives to something, which can be, potentially, anything. ${ }^{23}$ Timê refers then to the way thumos gives something a value into [in] a particular context. This complex operation of valuing things makes timê ambivalent: it refers both to the act of "valuing something" and to an "object" which is actually the result of the process of valuing things in a given society which has its own set of values. ${ }^{24}$ In that respect, thumos's force is at once a threat and a potential auxiliary to reason's rule.

In the Phaedrus the tripartite model of the soul is a means used by Plato to neutralize philotimia, focusing on its seat, thumos. The soul's partitioning enables Plato to locate the causes of love and act on them in order to transfigure them. A close reading of the central part of the charioteer's myth in the Phaedrus shows that thumos is actually the seat of many erotic effects $^{25}$. It is then necessary to address a discourse to thumos in order to persuade it to care for the rational part of the soul, the "true self", represented by the coachman. Plato keeps thumos as a mover, but neutralizes its propensity to corrupt intellectual love.

In the last part of the myth, Socrates depicts the effects of love on the lover using a physiological vocabulary that is often related to thumos:

20 The interpretation of the tripartite soul is, of course, a much-debated issue. Here I take as given a minimal reading of the tripartite model, as an intentional trifunctional structure, in which each function (reason, thumos and appetite) is capable of only one kind of operation. Reason is a calculative function, appetite is a conative force, and thumos is a "valuing function". Whereas book IV of the Republic presents each function as an autonomous agent, they are actually parts of an entire psychic structure in books VIII and IX. See, if I may, Renaut (2005) for such a reading, along with the relevant bibliography.

${ }^{21}$ Hobbs (2000) 30 .

${ }^{22}$ Such an ideology is severely condemned by Socrates in the Republic. According to Socrates, timê, considered through its object, inevitably comes to focus on money, as if philotimia were only a mask for cupidity and the striving for wealth. The explanation runs as follows: in his quest for honour, one is surreptitiously driven to seek the means of acquiring it; as wealth could appear as a symbol of honour and public esteem, a philotimos could be easily corrupted into a philochrêmatos. See Rsp. 345a3-6, 390e9 where Socrates condemns Achilles for desiring a ransom, 547b7-549b9 where Socrates analyses how the philotimos is corrupted by love of money, and $550 \mathrm{c} 11-553 \mathrm{~d} 7$, which depicts the oligarchic man who only values money. c4 ).

${ }^{23}$ See for example the democratic man, who considers that all things have the same "value" (561b8-

${ }^{24}$ Many passages in the Republic compare the real and objective values with false ones: $336 \mathrm{e} 8$ on justice compared with gold, 485b6-8 on Forms compared to traditional objects of enquiry, 509a4-5 on the supreme value of the Good, 591b4-7 on the soul compared to the body, 595c2-3 on the respect which is due to truth compared to the respect due to a man.

${ }^{25}$ As Cairns (1993) 384-5 has shown. 
O. Renaut, "Challenging Platonic Erôs. The Role of Thumos and Philotomia in Love", in E. Sanders, C. Thumiger, C. Carey \& al. (ed.) Erôs in Ancient Greece, Oxford, Oxford University Press, 2013, p. 95-110.

\begin{abstract}
Once he has looked at him, his chill ( $\dot{\varepsilon} \kappa \tau \tilde{\eta} \varsigma \varphi \rho i ́ \kappa \eta \varsigma)$ gives way to sweating and a

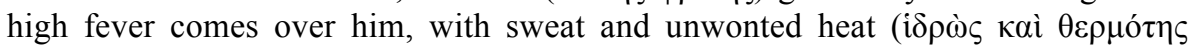

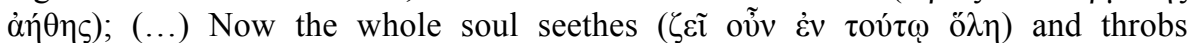

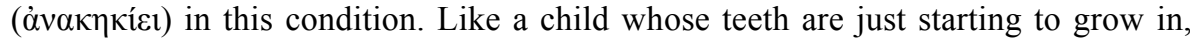

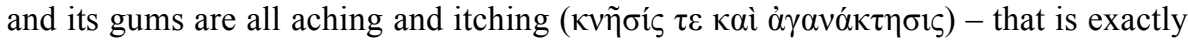
how the soul feels when it begins to grow wings. It swells up and aches and tingles

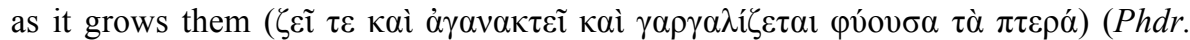
251a7-c5, trans. Nehamas and Woodruf).
\end{abstract}

In this description, it is the whole soul that endures the affections of love such as sweating, blushing, throbbing, and so on. But in other passages of the dialogues, these symptoms refer to the state of the thumos. ${ }^{26}$ These symptoms are more particularly related to the emotion of shame. ${ }^{27}$ Here, Socrates seems to speak by way of metonymy, using the word "soul" to refer to "thumos", which is merely of part of the soul. Why so? Certainly because the feelings aroused by the encounter between the lover and the beloved are always mixed, never reducible to sexual or intellectual feelings. It is then the thumos which is at stake here, for it is an emotional centre from which arises, after reflection, two other poles, epithymêtikon and logistikon. As the passage continues, Socrates proposes a more precise explanation:

\begin{abstract}
Now when the charioteer looks in the eye of love, his entire soul is suffused with a sense of warmth and starts to fill with tingles and the goading of desire. As for the horses, the one who is obedient to the charioteer is still controlled, then as always, by its sense of shame, and so prevents itself from jumping on the boy (o $\mu \dot{\varepsilon} v$

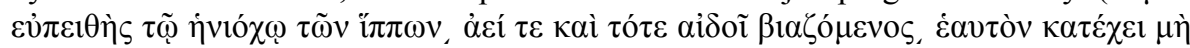
$\dot{\varepsilon} \pi \imath \pi \eta \delta \tilde{\alpha} \nu \tau \tilde{\varphi} \dot{\varepsilon} \rho \omega \mu \varepsilon \dot{\varepsilon} v \omega)$. The other one, however, no longer responds to the whip or

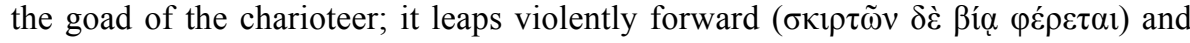
does everything to aggravate its yoke mate and its charioteer, trying to make them go up to the boy and suggest to him the pleasures of sex. At first the other two resist, angry in their belief that they are being made to do things that are dreadfully wrong

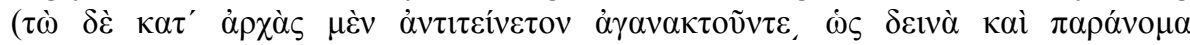

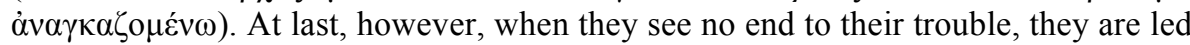
forward, reluctantly agreeing to do as they have been told. (Phdr. 253e5-254b3, trans. Nehamas and Woodruf)
\end{abstract}

What Socrates describes in this passage is very similar to the psychic conflict Leontios endures in book IV of the Republic (439b-c). The verb " $\dot{\alpha} \gamma \alpha v \alpha \kappa \tau \varepsilon \tilde{\imath}$ ", used to characterize the entire soul in the previous passage, now refers specifically to the struggle between the charioteer and the good horse on the one hand, and the bad horse on the other. The good

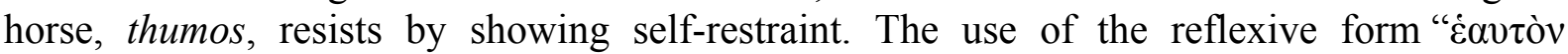
$\kappa \alpha \tau \varepsilon ́ \chi \varepsilon 1$ " is quite remarkable here, for Plato normally uses these expressions to refer to the way an individual represents himself, torn between several motivations. ${ }^{28}$ Here, Socrates seems to refer to the individual not by metonymy, but by synecdoche. In other words, it is as if the good horse were referring to the whole individual, and not one particular part of the soul. Here thumos denotes the real "I", showing self-restraint, representing the emotions as if they were in another part of the soul.

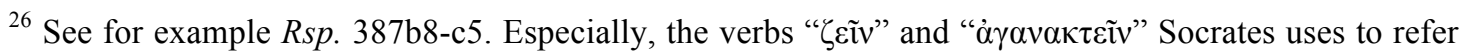
to thumoeidic character, or more precisely to thumos itself: Cra. 419e, Phd. 64a8, Rsp. 440c7 and 536c1, and Ti. $70 \mathrm{~b} 3$.

${ }^{27}$ See for example Thrasymachus in Rsp. 350c12-d3. See also Ti. 84d2-e2. On the poetic legacy of the imagery of the charioteer and his symptoms in the Phaedrus, see Cairns (this volume).

${ }^{28}$ See for example Rsp. 430e-431a, in which Socrates analyses the meaning of the expression "to be master of oneself". 
O. Renaut, "Challenging Platonic Erôs. The Role of Thumos and Philotomia in Love", in E. Sanders, C. Thumiger, C. Carey \& al. (ed.) Erôs in Ancient Greece, Oxford, Oxford University Press, 2013, p. 95-110.

Finally, Socrates gives us a hint in the following description:

At the sight he is frightened (" $\varepsilon \varepsilon 1 \sigma \varepsilon)$, falls over backwards awestruck $(\sigma \varepsilon \varphi \theta \varepsilon i \tilde{\sigma} \alpha)$, and at the same time has to pull the reins back so fiercely that both horses are set on their haunches, one falling back voluntarily with no resistance, but the other insolent and quite unwilling. They pull back a little further; and while one horse drenches the

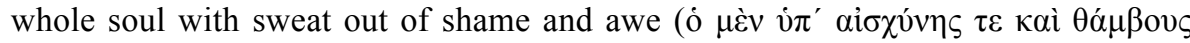

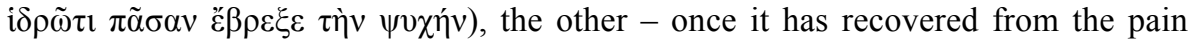
caused by the bit and its fall - bursts into a torrent of insults ( $\mu$ ó $\gamma 1 \varsigma \dot{\varepsilon} \xi \alpha v \alpha \pi v \varepsilon v 0 \alpha \varsigma$

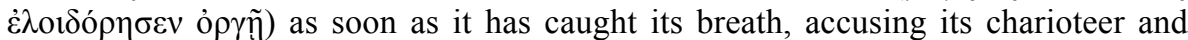
yokemate of all sorts of cowardice and unmanliness for abandoning their position

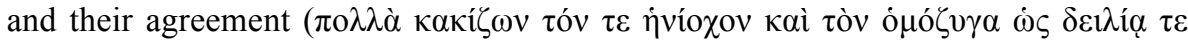

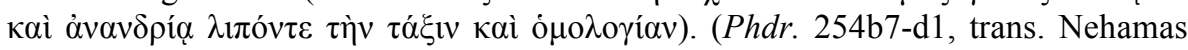
and Woodruf).

At first glance, Plato seems to complicate the tripartite model of the soul in ascribing to each part of the soul some features that normally belong to another. The charioteer feels two emotions, fear (deô) and religious awe (sebô), that are traditionally linked with thumos. But, conversely, the bad horse feels anger (orgê), which is, of course, what the thumos feels in Book IV of the Republic (439e-441a). It can be argued that this blurring of symptoms is intentional. All these emotions are, up to a point, one and the same, but seen from different points of view: as in the previous passages, the thumos is made responsible for shame (aischunê); this very same feeling is felt in an intellectualized form by the charioteer (sebas), whereas the bad horse transforms this shame into anger. Thumos, in this description, is the focal point from which stems different perceptions of the beloved, gradually referring to different parts of the soul. To put it as briefly as possible, in these three passages, thumos is both the focal point of the description and the psychic intermediary between reason and appetite. The thumos plays a twofold role: as the first and immediate function of the soul to feel the effects of love, thumos is the main addressee of erotic discourses; but, as an intermediary, it defeats (or tries to defeat) sexual desires, builds a relationship founded on mutual love and respect, and helps give rise to philosophical love. In focusing the description of the effects of love from the viewpoint of thumos, Socrates tries to convert its motivational force into philosophy.

Thumoeidic lovers are consequently positively depicted at the end of the myth:

If, on the other hand, they adopt a lower way of living, with ambition in place of

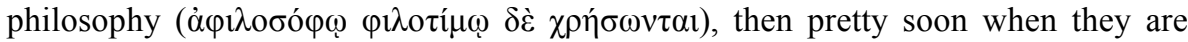
careless because they have been drinking or for some other reason, the pair's

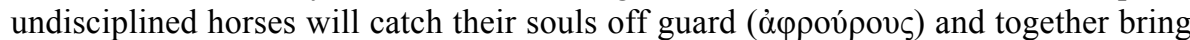
them to commit that act which ordinary people would take to be the happiest choice of all; and when they have consummated it once, they go on doing this for the rest of their lives, but sparingly, since they have not approved of what they are doing with

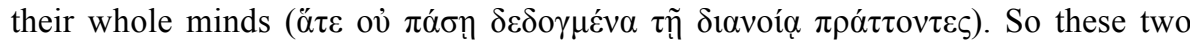
also live in mutual friendship ( the philosophical pair), both while they are in love and after they have passed

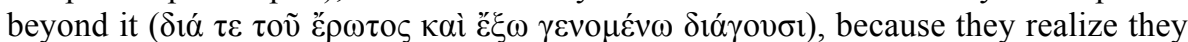

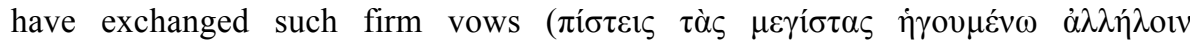

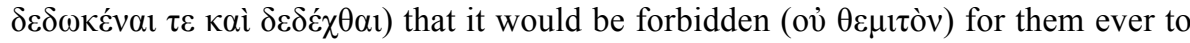
break them and become enemies. In death they are wingless when they leave the body, but their wings are bursting to sprout, so the prize they have won from the

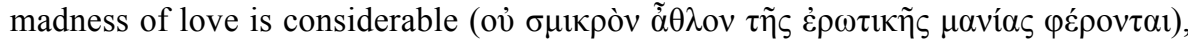
because those who have begun the sacred journey in lower heaven may not by law be sent into darkness for the journey under the earth; their lives are bright and happy

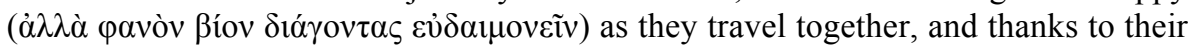


O. Renaut, "Challenging Platonic Erôs. The Role of Thumos and Philotomia in Love", in E. Sanders, C. Thumiger, C. Carey \& al. (ed.) Erôs in Ancient Greece, Oxford, Oxford University Press, 2013, p. 95-110.

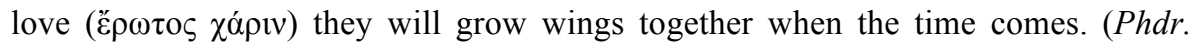
256b7-e2, trans. Nehamas and Woodruf)

Three points must be made on this rehabilitation of thumoeidic lovers.

First, their lives are provided with happiness. This happiness is of course less valuable, for it is understood as an intermediary between the regimen of philosophy and what the "ordinary people" would understand as true happiness. Their "friendship" is then weaker than that of philosophers, but nevertheless not to be underestimated (ou smikron). Moreover, this passage should not be understood as a mere hierarchical and static comparison, but as the second prize of a competition; thumoeidic love, made compatible with friendship, should be understood in terms of a mundane and promising temporality. In that sense, philotimia is a necessary intermediary that allows the transformation of a common and popular conception of love into a less bestial relationship.

Second, it seems here that an ideal form of erôs is to be found in mutual friendship (philia), challenging the issue of sexual intercourse in the relationship. Sexual intercourse is not absent, but only had seldom, if ever. Again, Socrates seems to stress here the anthropological origin and dynamic of this kind of love. Erôs is not discarded, but modified by the bonds of philia in weakening physical and sexual attachment.

Third, philotimia uses thumos' force as a "guard" (phrouros), using social and political bonds: judgments (dogma), marks of trust and confidence (pistis), under the guidance of a rule (themis). These three means are, again, derivative ones compared to reason's rule (and in that respect are "imperfect" ones), but are nevertheless an aid the philosopher uses to shape, as far as possible, human and personal love into a superior type of relationship.

\section{Restrained love in the polis}

If after all the Phaedrus does not deny the power of thumos in love, the persuasion and education of the thumos remains a difficult problem. This goal is reached in educating the thumos of individuals and using the very same feelings of shame and sense of honour to regulate erotic relationships in the polis: in the Republic, the Statesman, and the Laws, sexual and marital prescriptions are implied at the very beginning of a broader paideia, to prevent the individual from yielding power to bodily desires and also to a personal attachment that could lead to sexual intercourse. ${ }^{29}$ But, more essential to this political program in the Republic and the Laws, is the way Plato transfigures thumos's force in giving it a new object. Traditional feelings such as aidôs and philotimia are dissociated from the object they usually pursue and are used for the purpose of education, for example in the Laws. A famous passage of book VIII in the Laws about the regulation of sexual practices confirms it. As "guardians" of sexual appetites and pleasures (aphrodision), theosebas (a religious awe that inevitably recalls the sebas of the charioteer in the Phaedrus), and philotimia (like Phaedrus' speech in the Symposium) help the individual both to resist sexual attraction and to intellectualize their object of love.

ATHENIAN: My point is that the appetite for pleasures, which is very strong and

${ }^{29}$ On the subject, see the thorough analysis of Ludwig (2007), who shows that thumos in the Republic has a "vital connection" to philia and possessiveness (p. 223). I agree with Ludwig that erôs in the ideal state of the Republic should be disconnected from thumos, as far as the philosopher is concerned. But it seems slightly exaggerated to say that "there is a tragic paradox, since the thumos that enables citizen virtue also prevents the ascent to philosophic virtue" (p. 228), for if the citizen in question is definitely a non-philosopher, there is nothing "tragic" about it. But, in the pedagogical and psychagogic context of the Phaedrus, as I have tried to show, even if thumos is inclined to philotimia as such, the object which is valued can be modified. 
O. Renaut, "Challenging Platonic Erôs. The Role of Thumos and Philotomia in Love", in E. Sanders, C. Thumiger, C. Carey \& al. (ed.) Erôs in Ancient Greece, Oxford, Oxford University Press, 2013, p. 95-110.

grows by being fed, can be starved (you remember) if the body is given plenty of hard work to distract it. We'd get much the same result if we were incapable of having sexual intercourse ( $\dot{\alpha} \varphi \rho o \delta ı \sigma i \omega v)$ without feeling ashamed ( $\dot{\alpha} v \alpha i ́ \delta \varepsilon 1 \alpha)$; our shame ( $\left.\delta i^{\prime} \alpha i \sigma \chi v ́ v \eta v ~ \chi \rho \omega ́ \mu \varepsilon v o r\right)$ would lead to infrequent indulgence, and infrequent

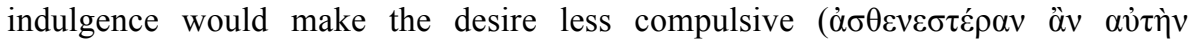
$\delta \varepsilon \dot{\sigma} \sigma \mathrm{olv} \alpha v)$. So in sexual matters our citizens ought to regard privacy - though not complete abstinence - as a decency ( $\tau 1 \kappa \alpha \lambda$ òv) demanded by usage and unwritten

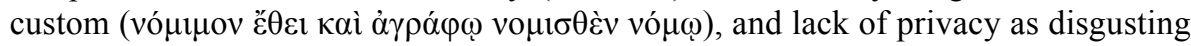
( $\alpha i \sigma \chi \rho o ́ v)$. That will establish a second legal standard of decency and indecency not the ideal standard, but the next to it. People whose characters have been corrupted (they form a single group we call the 'self-inferior') will be made prisoners of three influences that will compel them not to break the law

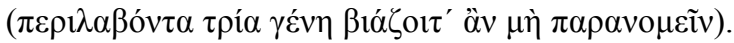

CLINIAS: What influences do you mean?

ATHENIAN: Respect for religion, the ambition to be honoured, and a mature passion

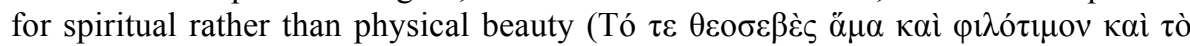

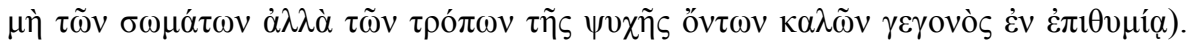
'Pious wishes!' you'll say; 'what romance!' Perhaps so. But if such wishes were to come true, the world would benefit enormously. (Leg. VIII, 841a6-c8, trans. Saunders)

The Athenian uses shame and philotimia as an ideological way to attain a "second degree of rectitude" for the community's behaviour. For it is not by means of the erotic skills of Socrates that a legislator of a city could lead the citizens to real and philosophical virtue, but instead through the promotion of unwritten law and internalized norms. In this passage, the same feelings which, for example, threatened the philosophical success of Socrates when educating Alcibiades in the Symposium, are used to counteract bodily desires and lust. There is indeed a political and pedagogical use of philotimia in preventing the city from corruption. But this use is ultimately founded on philosophical grounds, according to which thumos, the intermediate part of the soul, can be used as a force for the conversion to philosophy. Plato's task could be summed up as follows: a) given a human nature prone to thumoeidic affections, and $b$ ) given a function of the soul that is absolutely central to valuing things, the individual should be educated in a way that c) thumos and generally speaking philotimia should be purified from his concern about timê, and d) thumos should not be an obstacle to seeing the real object of love.

Aristotle himself, in book 7 of his Politics, seems to confirm this interpretation, asserting that Plato is well aware of the traditional link between thumos and philia. Recalling how the Guardians in the Republic are organized in a community based on mutual friendship, Aristotle makes thumos the function of the soul whereby we feel philia:

For as to what is said by certain persons about the character that should belong to their Guardians - they should be affectionate to their friends but fierce towards

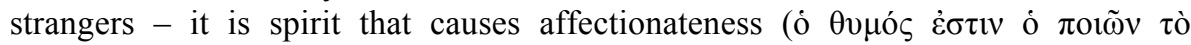

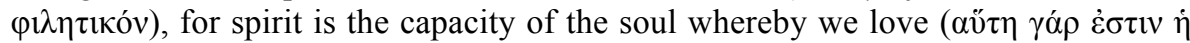

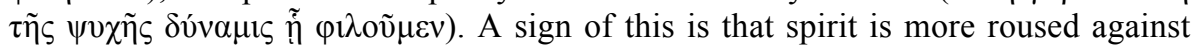
associates and friends than against strangers, when it thinks itself slighted. Therefore, Archilochus for instance, when reproaching his friends, appropriately apostrophizes his spirit: 'For 'tis thy friends that make thee choke with rage' (Pol. VII.7, 1327b38-a5, trans. Rackham).

The expression "the capacity of the soul whereby we love" inevitably recalls the way Socrates introduces the three functions of the soul in book IV of the Republic (436a8-b3). ${ }^{30}$ For here,

30 See also Phd. 96b3-8, Tht. 184c4-7. For a clear discussion on the use of this formulation (instrumental dative + verb), see Macé (2006), 89-90, 189. 
Aristotle plays on two meanings of thumos: as a psychic function, and as pathos akin to anger. The more one feels philia for someone, the more one feels anger in finding oneself betrayed. In a way, thumos as pathos is a negative sign of philia and thus thumos as psychic function can be seen as the seat of philia. However, this passage raises two problems. First, Aristotle does not seem to speak about philia in the broad sense of affectionateness, but in a narrower sense which does not include erôs as physical and sexual attachment. ${ }^{31}$ So we might wonder if, in Plato, erôs would essentially be linked with thumos as a function of the soul. Second, what is rather odd in this passage is that Aristotle quotes Archilochus and Euripides as evidence of the traditional link between philia and thumos, not Plato. Actually, Plato did not use this formulation in any dialogue, even in book II of the Republic, which is certainly the passage Aristotle has in mind, in which Socrates says that the thumoeides should not be aggressive towards relatives, balancing its violence with reason's softness (Rsp. 375b-e). But Aristotle seems to take for granted that Plato followed the tradition in placing affectionateness, or more precisely the philia that characterizes the bonds of the Guardians, in thumos. Why so? The reason for such confidence in placing philia in thumos is that the latter is, in Plato's dialogues, the seat of philotimia, a feeling that bonds people (whether citizens or soldiers) together through shared values of mutual assistance and reciprocal esteem. We can now understand why it is important, as Aristotle would claim for philia, to make thumos a central function for love. Even if Plato never said it explicitly, thumos could be the function of the soul whereby we "love", specifically, the seat of the reflexive emotions of shame and the sense of honour which, when they are felt repeatedly in pedagogical training, can defeat a popular and vulgar representation of love.

\section{Conclusion}

Platonic love, embodied by a philosophic way of life, must be understood as a model, a new horizon by which other forms of love can be judged and measured. In that respect, philotimia, which may be for us today more akin to "personal love", is certainly criticized as being founded on a wrong image of what deserves to be loved. Nevertheless, philotimia, as the tripartite model of the soul shows, is still an intermediary, more human, maybe less abstract love, through which those who are not philosophers can experience, even imperfectly, some characteristics of philosophic love. Even if the thumoeidic lovers are second in the scale of love, they appear to be a major concern from an anthropological and political perspective. As a psychic guardian, thumos must then be educated to transform the energy of philotimia to restrain physical and sexual desires. Thus, "personal love", even if it is not a valid form of love, remains a starting point before philosophy transforms it.

Olivier RENAUT

Université Paris Ouest - Nanterre-La Défense

\section{Bibliography}

${ }^{31}$ I thank C. Gill for having pointed out this issue to me. This chapter of the Politics is entirely devoted to the way the Guardians of the Republic live together. Hence the insistence on the military context of the poetic quotations from Archilochus and Euripides. However, insofar as the community formed by the Guardians in the Republic implies a reform of sexual regulations, we may wonder whether the word "philêtikon" does include more erotic relationships. It is certainly the case in Aristotle's view, but not in Plato's. On this topic, see Leontsini and Gill (this volume). 
O. Renaut, "Challenging Platonic Erôs. The Role of Thumos and Philotomia in Love", in E. Sanders, C. Thumiger, C. Carey \& al. (ed.) Erôs in Ancient Greece, Oxford, Oxford University Press, 2013, p. 95-110.

Adkins A.W.H. (1982), "Values, Goals, and Emotions in the Iliad", Classical Philology 77, $\mathrm{n}^{\circ} 4,292-326$.

(1996), "The Speech of Lysias' in Plato's Phaedrus", in B. Louden and P. Schollmeier (eds.), The Greeks and us: Essays in honor of Arthur W.H. Adkins, Chicago: The University of Chicago Press, 224-40.

Brès Y. (1973), La Psychologie de Platon, Paris: Presses Universitaires de France.

Cairns D. L. (1993), Aidos: the Psychology and Ethics of Honour and Shame in Ancient Greece, Oxford: Clarendon Press.

Carone G. R. (2006), "The Virtues of Platonic Love", in J. Lesher, D. Nails, F.C.C. Sheffield (eds.), Plato's Symposium: Issues in interpretation and reception, Hellenic Studies 22, Cambridge, MA: Harvard University Press, 208-26.

Corrigan K. \& Glazov-Corrigan E. (2006), Plato's Dialectic at Play, Argument, Structure and Myth in the Symposium, University Park: The Pennsylvania State University Press.

Gill C. (1990), "Platonic love and individuality", in A. Loizou, H. Lesser (eds.) Polis and Politics. Essays in Greek moral and political Philosophy, Averbury: Aldershot, 69-88.

Hobbs A. (2000), Plato and the Hero: Courage, Manliness, and the Impersonal Good, Cambridge: Cambridge University Press.

Larrivée A. (2005), "Malaise dans la cité. Éros et Tyrannie au livre IX de la République", in M. Dixsaut (dir.), avec la collaboration d'A. Larivée, Études sur la République de Platon, vol.1 De la justice ; éducation, psychologie et politique, Paris, Vrin, p.169-97.

Ludwig P. W. (2007), "Eros in the Republic", in G.R.F. Ferrari (dir.), The Cambridge Companion to Plato's Republic, Cambridge: Cambridge University Press, 202-31.

Macé A. (2006), Platon, philosophie de l'agir et du pâtir, Sankt Augustin: Academia Verlag.

Nehamas A. and Woodruf P. (trans.), Plato, The Symposium, in J. M. Cooper (dir.), Plato, Complete works, Indianapolis: Hackett Publishing, 1997.

Nehamas A. and Woodruf P. (trans.), Plato, Phaedrus, in J. Cooper (dir.), Plato, Complete works, Indianapolis: Hackett Publishing, 1997.

Nussbaum M. C. (2001), The Fragility of Goodness: Luck and Ethics in Greek Tragedy and Philosophy, 2nd ed., Cambridge: Cambridge University Press.

Price A. W. (1981), "Loving Persons Platonically", Phronesis 26, 25-34.

Renaut O. (2007), "Les conflits de l'âme dans la République", Etudes Platoniciennes 4, 183 203.

Rackham H. (trans.), Aristotle, Politics, Cambridge (Mass.): Harvard University Press, 1944.

Riedinger J.- C. (1976), "Remarques sur la timê chez Homere", Revue des Etudes Grecques $89,244-64$.

Robin L. (1964), La Théorie platonicienne de l'amour, Paris: Presses Universitaires de France.

Rowe C. (1990), "Philosophy, love, and madness", in C. Gill (ed.), The Person and the Human Mind, Issues in Ancient and Modern Philosophy, Oxford: Clarendon Press, 227-46.

Saunders T. J. (trans.), Plato, Laws, Harmondsworth: Penguin Books, 1975.

Souilhé J. (1919), La Notion platonicienne d'intermédiaire dans la philosophie des Dialogues, Paris: Félix Alcan.

Vlastos G. (1981), "The individual as an object of love in Plato", in Platonic Studies, Princeton: Princeton University Press, 3-42.

Wersinger A.-G. (2001), Platon et la dysharmonie: Recherches sur la forme musicale, Paris: Vrin.

White F. C. (1990), "Love and the Individual in Plato's Phaedrus", Classical Quarterly 40, $\mathrm{n}^{\circ} 2,396-406$. 